\title{
Responsiveness of Occupational Health Risk and Preventive Measures Practice by the Workers Employed in Tannery Occupation in Kanpur, India
}

\section{Gyan Chandra Kashyap ( $\sim$ gyan@iihmr.org )}

Institute of Health Management Research

\section{Praveen Chokhandre}

International Institute for Population Sciences

Shri Kant Singh

International Institute for Population Sciences

\section{Research}

Keywords: Occupational Health Risk, Preventive Measures, Tannery Workers, Awareness, Exposure of Hazardous Chemicals, Work Environment, Health Hazard, Qualitative measure

Posted Date: January 13th, 2020

DOI: https://doi.org/10.21203/rs.2.20702/v1

License: (c) (i) This work is licensed under a Creative Commons Attribution 4.0 International License. Read Full License 


\section{Abstract}

Background: Occupational health covers all aspects of health and safety in the workplace and has a strong focus on primary prevention of hazards. There are several health risks, such as respiratory problems, injuries/accidents, musculoskeletal disorders, cancers, mental health disorders, skin ailments, infectious diseases, and many more involved in the occupation, which exclusively depends on workplace conditions.

Objectives: The objective of the study was to understand the extent of awareness about occupational health risks involved in tannery occupation and adopted preventive measures by the tannery workers of Kanpur, India.

Methods: Information for the present research was strained from a cross-sectional household study of tannery workers in the Jajmau area of Kanpur, India. The survey was piloted through the period January-June 2015, and 284 samples were collected. This study has adopted a three-stage sampling design. The frequency distribution and cross-tabulation were used. The difference in the awareness of various morbidities was tested using the chi-square test. A logistic regression analysis was used to identify individual risk factors.

Results: The prevalence of awareness of tannery work is very hazardous in nature varies from $73 \%$ to $93 \%$ among the tannery workers. Tannery workers having a middle-school level of education were 3.01 times more likely to be aware of the hazards as compared to the illiterate workers. Tannery workers aged 36 and above were 0.34 times were 0.58 times less likely to aware of a hazardous work environment. Tannery workers who belong to the younger cohort (16-24 years) reported a higher awareness of respiratory problems (38\%), skin complaints (59\%), and gastrointestinal issues (21\%) than those aged 36 years and above. About one-third of Beamhouse workers (33\%) and over a quarter (26\%) of the wet finishing had moderate to high dermal contact with the chemicals. The highest use of gloves and masks is seen in Beamhouse work (12\&13\%).

Conclusions: The outcomes of the study give a clear indication of the effect of the workstation environment on the health status of workers and require the use of adequate measures to improve the facilities and thereby the health status of tannery workers.

\section{Background}

The enormous burden of poor working conditions stated by several studies and with the latest estimates provided by the International Labour Organization (ILO) that somewhere 2.3 million working people around the world capitulate to workrelated accidents or diseases every year; this links to over 6000 deaths every single day. Worldwide, there are around 340 million occupational accidents and 160 million fatalities of work-related illnesses annually [1]. While Improved and harmless workplaces can avoid at least 1.2 million deaths every year, according to 2018 world health organization (WHO) study. Many causalities can be prevented through addressing significant health dangers, which is directly associated with the workplace, and the exposures such as stress, long working hours and shift work, prolonged sitting at work, workrelated climate-sensitive diseases, such as heat and cold stress, as well as workplace air pollution $[2,3,4,5]$.

Occupational health covers all aspects of health and safety in the workplace and has a strong focus on primary prevention of hazards. Depending on workplace conditions, there are several health risks: cancers, injuries/accidents, musculoskeletal disorders, respiratory problems, mental health disorders, skin ailments, infectious diseases, etc. Employment conditions in both formal and informal sectors are also significant factors: working hours, salary, and policies that cover such aspects as maternity leave, and provisions for protecting and promoting employee health [6]. Occupational health is a grave concern in developing countries, but there have been few studies of health issues faced by tannery workers because of which the problems are largely unknown. Further, the workers' health issues have not received sufficient attention from employers. The place and work environment are crucial influences on the extent of health risks 
faced by tannery workers. According to WHO, occupational health problems accounted for about 1.5 percent of the total burden of disease regarding disability adjusted life years (DALYs), particularly in occupational health, which included work-related injuries, and exposure to risks such as carcinogens, airborne particulates, ergonomic stressors, and noise [7].

Tannery workers are susceptible to multiple chemical and physical hazards in their work. Direct exposure to hazardous materials significantly increases health risks. The workers are exposed to chromium during the tanning process, leather dust, and various chemical agents. There are also ergonomic stressors that increase susceptibility to numerous health issues. Workers involved in multiple operations like material transfer, wet finishing, dry finishing, etc. are particularly vulnerable to harm. The risks associated with the tanning work is included in the proposed research paper examines the health hazards of tannery work Kanpur (India), and the preventive actions that are taken.

As mentioned earlier, there have been a limited number of studies of perceived health risks and preventive measures among tannery workers in the developing world. This research work investigates the work experience, working hours, type of job contract, and the type of work the tannery employees are usually engaged in. At the same time, it also examines their awareness of the hazardous work environment, the effect of exposure to chemicals, dangerous tissues involved in the tanning process. It also studies their perceptions of the effects of exposure to chemicals and contact with them, airborne dust, and ergonomic stressor. The objective of the study was to understand the extent of awareness about occupational health risks and adopted preventive measures during working hours among male tannery workers of Kanpur, India.

\section{Methods}

Information for the present research was strained from a cross-sectional household study of tannery workers in the Jajmau area of Kanpur, India. The survey was piloted through the period January-June, 2015, and was a portion of a Ph.D. database. All total of 286 tannery workers from the study area were questioned. Rigorous pre-testing was completed with the tannery workers of the Jajmau area for testing the internal uniformity of schedule. Beforehand starting the interviews, we have clarified the tenacity of the survey and requested to contribute to the study by giving the proper information. After that, face-to-face discussions were piloted among those who agreed to participate in the study by using a structured pre-tested questionnaire on the tannery workers. Appropriate statistical methods were used to meet the objectives of the study.

\section{Sampling Design}

This study has adopted a three-stage sampling design. At the first stage, seven localities in the Jajmau area, namely Tadbagiya, Kailash Nagar, J.K. colony, Asharfabad, Motinagar, Chabeelepurwa, and Budhiyaghat, were selected based on a higher concentration of leather tannery worker's population in these areas as reported by various stakeholders in the city. In the second stage, three out of the seven localities, namely Budhiyaghat, Tadbagiya, and Asharfabad, were selected by probability proportional to size (PPS) sampling technique after arranging them in increasing order of estimated number of HHs of leather tannery workers. Subsequently, a comprehensive household listing and mapping were completed in each of the three localities, and all the household were classified into three groups-households having at least one tannery worker, irrespective of having or not having any non-tannery worker, households having non-tannery worker (s) and households having no worker. The first two groups of households constituted two independent sampling frame in each of the three selected localities. While the third group of households was excluded from the study. Once the updated and comprehensive sampling frames were developed in each of the three areas included in the study, a circular systematic random sampling was used for the selection of households at the third and the last stage. In case, if more than one worker were in a household, the target respondent was selected using KISH table. In each of the three selected areas, 100 households were selected for each of the two categories i.e., a tannery as well as non-tannery workers, using a 
circular systematic random sampling procedure. Thus, a total of $600 \mathrm{HHs}$ were selected for the interview, and a total of $284 \mathrm{HHs}$ having at least tannery workers, and $289 \mathrm{HHs}$ of non-tannery workers (s) were interviewed successively. In the paper, we have tried to understand the level of awareness among the leather tannery workers. Bivariate analysis and logistic regression analysis is performed.

\section{Results}

\section{Work related characteristics of tannery workers}

The work-related characteristics of tannery workers are presented in Table 1. Tannery operations can be categorized into four broad categories: Beamhouse work ( $8 \%$ of workers in a tannery unit), wet finishing (25\%), dry finishing (50\%), and miscellaneous work (17\%).

Table 1: Work related characteristics of tannery workers

\begin{tabular}{lcc}
\hline Variables & Percentage (\%) & Number (N) \\
\hline Type of job within tannery occupation & & \\
\hline Beam house & 8.4 & 24 \\
\hline Wet finishing & 50.4 & 70 \\
\hline Dry finishing & 16.7 & 442 \\
\hline Miscellaneous & & 48 \\
\hline Work experience in current tannery & 34.3 & 96 \\
\hline Up to 5 years & 33.5 & 96 \\
\hline 6 to 10 years & 22.4 & 64 \\
\hline 11 to 20 years & 9.8 & 28 \\
\hline $20+$ years & & \\
\hline Work experience in previous tannery & 43.4 & 43 \\
\hline Up to 5 years & 38.4 & 38 \\
\hline 6 to 10 years & 13.1 & 13 \\
\hline 11 to 20 years & 5.1 & 5 \\
\hline 20+ years & & \\
\hline Type of job contract & 89.2 & 253 \\
\hline Temporary job (daily wages) & 10.8 & 31 \\
\hline Permanent job & & \\
\hline Working hours in day & 47.2 & 134 \\
\hline 7 to 8 hours & 25.5 & 73 \\
\hline 9 to 10 hours & 27.3 & 77 \\
\hline 11 to 12 hours & & \\
\hline Working days in a week & 48.3 & 137 \\
\hline Six days in a week & 51.7 & 147 \\
\hline Seven days in a week & $\mathbf{1 0 0 . 0}$ & $\mathbf{2 8 4}$ \\
\hline Total &
\end{tabular}

We collected information on total work experience (in the present job and previous ones) in tanneries. Around 15 percent of the tannery workers surveyed were engaged in the occupation for more than 20 years, and about one-third of workers were involved for 20 years in the tannery occupation. Most of the workers (89\%) were working as daily wage laborers, while only 11 percent were permanent employees. Over one-fourth (27\%) worked for 11 to 12 hours a day, and 52 percent reported that they worked for all seven days in the week. 
The nature of the work done is shown in Figure 1. For this study, the job contract was divided into two categories-temporary (daily wages) and permanent. Most workers were engaged in works on a temporary basis. In the beam house, where the work is particularly hazardous, 96 percent of the workers were employed temporarily, with permanent employees making up the remainder. The nature of the job contract was heavily skewed in the other sections also: wet finishing work (84\% and 16 percent respectively of temporary and permanent workers), dry finishing (89\% and 11\%), and miscellaneous work (94\% and 6\%).

\section{Awareness about the exposure of hazardous chemicals and work environment}

Workers' awareness of hazards involve in tannery operation is presented in Table 2. About 79 percent of the workers in the age group of 16-24 years agreed with the statement that "tannery work is very hazardous in nature" found to be highest. Awareness of the above statement varies from 73 to 93 percent for the educational attainment, religion, caste, media exposure, and standard of living index among the tannery workers. It was found that tannery workers having a middle-school level of education were 3.01 times more likely to be aware of the hazards as compared to the illiterate or less educated ones. Those with a comparatively higher standard of living were 2.08 times more likely to agree that "tannery work is very hazardous in nature" than those having a lower standard of living. Agreement with the statement that "tannery workers work in the very hazardous work environment" ranges from 55-79 percent for the predictors such as age, education, religion, caste, media exposure, and standard of living index. Tannery workers aged 36 and above were 0.34 times, and those who had a medium level of media exposure were 0.58 times less likely to aware of a hazardous work environment. We also examined the perceptions about exposure to hazardous chemicals in tanning processes. The awareness varied between 40 and 69 percent according to selected background variables. Odds ratio show that workers having a middle level of education were 0.43 times, and those with a medium level of media exposure are 0.54 times less likely to aware of the exposure of hazardous chemicals used in the tanning process. We also tried to understand the awareness of exposure to hazardous tissues involved in the tanning process. It was found that awareness ranged from 40 to 65 percent, depending on age, education, religion, caste, media exposure, and standard of living index. The odds ratio shows that tannery workers aged 36 years and above were 0.44 times less likely to aware of the hazardous tissues involved in the tanning process. 
Table 2: Awareness among the tannery workers about the involvement of hazards in tannery work by some selected background characteristics

\begin{tabular}{|c|c|c|c|c|c|c|c|c|}
\hline \multirow[t]{2}{*}{$\begin{array}{l}\text { Background } \\
\text { Variables }\end{array}$} & \multicolumn{2}{|c|}{$\begin{array}{l}\text { Tannery work is very } \\
\text { hazardous in nature }\end{array}$} & \multicolumn{2}{|c|}{$\begin{array}{c}\text { Tannery workers work in } \\
\text { hazardous work } \\
\text { environment }\end{array}$} & \multicolumn{2}{|c|}{$\begin{array}{l}\text { Tannery workers are exposed } \\
\text { to many hazardous chemicals }\end{array}$} & \multicolumn{2}{|c|}{$\begin{array}{l}\text { Hazardous tissues } \\
\text { involve in tanning } \\
\text { process }\end{array}$} \\
\hline & $\begin{array}{l}\text { Percent } \\
(\%)\end{array}$ & Odds CI & $\begin{array}{c}\text { Percent } \\
(\%)\end{array}$ & Odds CI & $\begin{array}{c}\text { Percent } \\
(\%)\end{array}$ & Odds CI & $\begin{array}{c}\text { Percent } \\
(\%)\end{array}$ & Odds CI \\
\hline \multicolumn{9}{|l|}{$\begin{array}{l}\text { Age in } \\
\text { years }\end{array}$} \\
\hline $16-24$ & 79.3 & & 79.3 & & 68.9 & & 65.5 & \\
\hline $25-35$ & 78.6 & $\begin{array}{l}1.23 \\
{[0.42-} \\
3.65]\end{array}$ & 65.0 & $\begin{array}{l}0.54 \quad[0.20- \\
1.49]\end{array}$ & 59.2 & $\begin{array}{c}0.71[0.28- \\
1.78]\end{array}$ & 55.3 & $\begin{array}{c}0.66 \\
{[0.27-} \\
1.62]\end{array}$ \\
\hline $36+$ & 74.3 & $\begin{array}{l}0.89 \\
{[0.31-} \\
2.57]\end{array}$ & 55.2 & $\begin{array}{l}0.34 * *[0.13- \\
0.93]\end{array}$ & 52.6 & $\begin{array}{c}0.55[0.22- \\
1.35]\end{array}$ & 46.0 & $\begin{array}{l}0.44^{*} \\
{[0.18-} \\
1.07]\end{array}$ \\
\hline \multicolumn{9}{|l|}{ Education } \\
\hline Illiterate & 73.8 & & 59.3 & & 57.7 & & 50.8 & \\
\hline $\begin{array}{l}\text { Up to } \\
\text { primary }\end{array}$ & 78.9 & $\begin{array}{l}1.27 \\
{[0.52-} \\
3.12]\end{array}$ & 63.1 & $\begin{array}{l}0.98[0.46- \\
2.10]\end{array}$ & 60.5 & $\begin{array}{l}0.98[0.46- \\
2.09]\end{array}$ & 55.2 & $\begin{array}{l}1.08 \\
{[0.51-} \\
2.28]\end{array}$ \\
\hline $\begin{array}{l}\text { Middle } \\
\text { school }\end{array}$ & 88.0 & $\begin{array}{l}3.01 * \\
{[0.73-} \\
12.34]\end{array}$ & 60.0 & $\begin{array}{l}0.94[0.36- \\
2.46]\end{array}$ & 40.0 & $\begin{array}{c}0.43 *[0.16- \\
1.14]\end{array}$ & 40.0 & $\begin{array}{c}0.66 \\
{[0.25-} \\
1.73]\end{array}$ \\
\hline $\begin{array}{l}\text { High school } \\
\& \text { above }\end{array}$ & 78.7 & $\begin{array}{l}1.23 \\
{[0.40-} \\
3.79]\end{array}$ & 69.7 & $\begin{array}{l}1.31[0.49- \\
3.49]\end{array}$ & 57.5 & $\begin{array}{l}0.78[0.30- \\
2.00]\end{array}$ & 57.5 & $\begin{array}{c}1.27 \\
{[0.50-} \\
3.23]\end{array}$ \\
\hline \multicolumn{9}{|l|}{ Religion } \\
\hline Hindu & 83.3 & & 64.5 & & 59.3 & & 47.9 & \\
\hline Muslim & 72.8 & $\begin{array}{c}0.63 \\
{[0.31-} \\
1.26]\end{array}$ & 59.5 & $\begin{array}{l}0.94[0.53- \\
1.66]\end{array}$ & 55.3 & $\begin{array}{c}0.94[0.53- \\
1.66]\end{array}$ & 53.1 & $\begin{array}{l}1.51 \\
{[0.86-} \\
2.66]\end{array}$ \\
\hline \multicolumn{9}{|l|}{ Caste } \\
\hline $\begin{array}{l}\text { Schedule } \\
\text { caste }\end{array}$ & 80.6 & & 61.8 & & 58.6 & & 51.0 & \\
\hline $\begin{array}{l}\text { Other } \\
\text { backward } \\
\text { class }\end{array}$ & 65.3 & $\begin{array}{c}0.41 * * \\
{[0.20-} \\
0.86]\end{array}$ & 59.6 & $\begin{array}{l}0.80[0.41- \\
1.57]\end{array}$ & 63.4 & $\begin{array}{c}1.14[0.58- \\
2.24]\end{array}$ & 61.5 & $\begin{array}{l}1.31 \\
{[0.67-} \\
2.55]\end{array}$ \\
\hline Others & 93.7 & $\begin{array}{l}4.60 \\
{[0.56-} \\
37.80]\end{array}$ & 62.5 & $\begin{array}{l}1.21[0.39- \\
3.76]\end{array}$ & 50.0 & $\begin{array}{c}0.84[0.28- \\
2.50]\end{array}$ & 50.0 & $\begin{array}{l}0.92 \\
{[0.31-} \\
2.74]\end{array}$ \\
\hline \multicolumn{9}{|l|}{$\begin{array}{l}\text { Media } \\
\text { exposure }\end{array}$} \\
\hline Low & 76.9 & & 64.6 & & 61.5 & & 53.8 & \\
\hline Medium & 74.6 & $\begin{array}{c}0.74 \\
{[0.35-} \\
1.59]\end{array}$ & 55.8 & $\begin{array}{l}0.58 *[0.30- \\
1.11]\end{array}$ & 52.1 & $\begin{array}{c}0.54 *[0.28- \\
1.03]\end{array}$ & 47.1 & $\begin{array}{c}0.59 \\
{[0.31-} \\
1.12]\end{array}$ \\
\hline High & 79.0 & $\begin{array}{c}0.64 \\
{[0.22-} \\
1.77]\end{array}$ & 67.9 & $\begin{array}{l}0.66[0.28- \\
1.57]\end{array}$ & 60.4 & $\begin{array}{c}0.83[0.35- \\
1.97]\end{array}$ & 56.7 & $\begin{array}{c}0.79 \\
{[0.34-} \\
1.85]\end{array}$ \\
\hline \multicolumn{9}{|l|}{$\begin{array}{l}\text { Standard of } \\
\text { living index }\end{array}$} \\
\hline Low & 73.8 & & 56.0 & & 52.3 & & 46.7 & \\
\hline Medium & 75.2 & $\begin{array}{l}1.17 \\
{[0.58-} \\
2.39]\end{array}$ & 60.6 & $\begin{array}{l}1.34[0.73- \\
2.49]\end{array}$ & 56.1 & $\begin{array}{c}1.18[0.64- \\
2.18]\end{array}$ & 50.5 & $\begin{array}{c}1.07 \\
{[0.58-} \\
1.98]\end{array}$ \\
\hline High & 80.6 & $2.08^{*}$ & 68.1 & $1.94 *[0.98-$ & 62.5 & $1.46[0.75-$ & 57.9 & 1.42 \\
\hline
\end{tabular}


The awareness of potential health hazards involved in the tanning process by type of work is presented in Table 3. It is seen that 83 wet finishing and dry finishing (about 80\%) workers were aware that the tannery work is hazardous. Similarly, 66 and 64 percent wet finishing and dry finishing workers engaged in tannery workers accepted that they worked in an unsafe work environment. Most of the workers (69\%) in the wet finishing section reported that tannery workers were exposed to several hazardous chemicals during the tanning process, which was following by workers engaged in dry finishing (55\%), Beamhouse work (50\%), and workers engaged in miscellaneous work (49\%). Around two-thirds of the workers involved in wet finishing were agreed that hazardous tissue engaged in the tanning process.

Table 3: Awareness about the health hazard involved in tanning process by their type of work they usually do in tannery.

\begin{tabular}{|c|c|c|c|c|c|c|}
\hline Statements & Beamhouse & Wet finishing & Dry finishing & Miscellaneous & Overall & $(\mathrm{N})$ \\
\hline \multicolumn{7}{|c|}{ Tannery work is very hazardous in nature } \\
\hline Agree & 62.5 & 82.9 & 80.4 & 61.7 & 51.4 & 217 \\
\hline Disagree & 37.5 & 17.1 & 19.6 & 38.3 & 48.6 & 67 \\
\hline \multicolumn{7}{|c|}{ Tannery workers work in hazardous work environment } \\
\hline Agree & 58.3 & 65.7 & 63.6 & 48.9 & 56.7 & 174 \\
\hline Disagree & 41.7 & 34.3 & 36.4 & 51.1 & 43.3 & 110 \\
\hline \multicolumn{7}{|c|}{ Tannery workers are exposed to many hazardous chemicals } \\
\hline Agree & 50.0 & 68.6 & 54.6 & 48.9 & 61.3 & 161 \\
\hline Disagree & 50.0 & 31.4 & 45.5 & 51.1 & 38.7 & 123 \\
\hline \multicolumn{7}{|c|}{ Hazardous tissues involve in tanning process } \\
\hline Agree & 41.7 & 58.6 & 50.3 & 48.9 & 76.4 & 146 \\
\hline Disagree & 58.3 & 41.4 & 49.7 & 51.1 & 23.6 & 138 \\
\hline Total & 100.0 & 100.0 & 100.0 & 100.0 & 100.0 & 284 \\
\hline
\end{tabular}

\section{Awareness about the health hazard due to work in tannery occupation}

This research work examined awareness of health problems that may occur in tannery work. Various health issues like respiratory trouble, skin complaints, eye-related, and gastrointestinal issues were observed, which are presented in Table 4. Tannery workers who belong to the younger cohort (16-24 years) reported a higher awareness of respiratory problems (38\%), skin complaints (59\%), and gastrointestinal issues (21\%) than those aged 36 years and above. There is an increasing awareness of educational attainment. Workers with high school education and more showed higher awareness of respiratory problems (52\%), skin complaints (67\%) in comparison to illiterate

tble 4: Percent distribution of tannery workers who were aware about the health problems involve in nery work 


\begin{tabular}{|c|c|c|c|c|c|c|c|c|}
\hline \multirow[b]{2}{*}{$\begin{array}{l}\text { Background } \\
\text { Variables }\end{array}$} & \multicolumn{2}{|c|}{$\begin{array}{c}\text { Respiratory } \\
\text { Problems }\end{array}$} & \multirow{2}{*}{$\begin{array}{c}\text { Skin } \\
\text { Complaints } \\
\text { Percent (\%) }\end{array}$} & \multirow[b]{2}{*}{ Chi-square } & \multicolumn{2}{|c|}{$\begin{array}{l}\text { Eye related } \\
\text { problems }\end{array}$} & \multicolumn{2}{|c|}{$\begin{array}{l}\text { Gastrointestinal } \\
\text { problems }\end{array}$} \\
\hline & $\begin{array}{c}\text { Percent } \\
(\%)\end{array}$ & $\begin{array}{c}\text { Chi- } \\
\text { square }\end{array}$ & & & $\begin{array}{c}\text { Percent } \\
(\%)\end{array}$ & $\begin{array}{c}\text { Chi- } \\
\text { square }\end{array}$ & $\begin{array}{c}\text { Percent } \\
(\%)\end{array}$ & Chi-square \\
\hline $\begin{array}{l}\text { Age in } \\
\text { vears }\end{array}$ & & \multirow{4}{*}{$\begin{array}{c}c 2=4.56 \\
p< \\
0.335\end{array}$} & & \multirow{4}{*}{$\begin{array}{l}c 2=1.76 \\
p<0.780\end{array}$} & & \multirow{4}{*}{$\begin{array}{c}c 2=13.89 \\
p<0.008\end{array}$} & & \multirow{4}{*}{$\begin{array}{l}\mathrm{c} 2=2.19 \\
\mathrm{p}<0.700\end{array}$} \\
\hline $16-24$ & 37.9 & & 58.6 & & 24.1 & & 20.6 & \\
\hline $25-35$ & 25.2 & & 53.4 & & 34.9 & & 13.5 & \\
\hline $36+$ & 23.6 & & 53.9 & & 38.1 & & 12.5 & \\
\hline \multicolumn{9}{|l|}{ Education } \\
\hline Illiterate & 19.2 & \multirow{4}{*}{$\begin{array}{c}c 2=19.48 \\
p<0.003\end{array}$} & 54.5 & \multirow{4}{*}{$\begin{array}{l}c 2=8.46 \\
p<0.206\end{array}$} & 37.4 & \multirow{4}{*}{$\begin{array}{l}\mathrm{c} 2=4.47 \\
\mathrm{p}<0.613\end{array}$} & 11.7 & \multirow{4}{*}{$\begin{array}{l}\mathrm{c} 2=11.86 \\
\mathrm{p}<0.065\end{array}$} \\
\hline $\begin{array}{l}\text { Up to } \\
\text { primary }\end{array}$ & 23.6 & & 39.4 & & 31.5 & & 7.8 & \\
\hline $\begin{array}{l}\text { Middle } \\
\text { school }\end{array}$ & 40.0 & & 56.0 & & 36.0 & & 24.0 & \\
\hline $\begin{array}{l}\text { High school } \\
\& \text { above }\end{array}$ & 51.5 & & 66.6 & & 27.2 & & 21.2 & \\
\hline \multicolumn{9}{|l|}{ Religion } \\
\hline Hindu & 33.3 & \multirow{2}{*}{$\begin{array}{c}c 2= \\
18.91 \\
p<0.000\end{array}$} & 55.2 & \multirow{2}{*}{$\begin{array}{l}c 2=1.14 \\
p<0.566\end{array}$} & 22.9 & \multirow{2}{*}{$\begin{array}{c}c 2=10.71 \\
p<0.005\end{array}$} & 15.6 & \multirow{2}{*}{$\begin{array}{l}c 2=1.11 \\
p<0.575\end{array}$} \\
\hline Muslim & 21.8 & & 53.7 & & 42.0 & & 12.7 & \\
\hline \multicolumn{9}{|l|}{ Caste } \\
\hline $\begin{array}{l}\text { Schedule } \\
\text { caste }\end{array}$ & 22.5 & \multirow[t]{3}{*}{$\begin{array}{r}c 2=26.26 \\
p<0.000\end{array}$} & 54.3 & \multirow[t]{3}{*}{$\begin{array}{l}\mathrm{c} 2=7.65 \\
\mathrm{p}<0.265\end{array}$} & 34.4 & \multirow[t]{3}{*}{$\begin{array}{c}c 2=22.02 \\
p<0.001\end{array}$} & 10.2 & \multirow[t]{3}{*}{$\begin{array}{l}\mathrm{c} 2=24.80 \\
\mathrm{p}<0.000\end{array}$} \\
\hline $\begin{array}{l}\text { Other } \\
\text { backward } \\
\text { class }\end{array}$ & 28.8 & & 57.6 & & 46.1 & & 19.2 & \\
\hline Others & 12.5 & & 62.5 & & 6.25 & & 0.0 & \\
\hline \multicolumn{9}{|l|}{$\begin{array}{l}\text { Media } \\
\text { exposure }\end{array}$} \\
\hline Low & 36.9 & \multirow{3}{*}{$\begin{array}{r}c 2=23.45 \\
p<0.000\end{array}$} & 61.5 & \multirow{3}{*}{$\begin{array}{l}c 2=5.48 \\
p<0.241\end{array}$} & 35.3 & \multirow{3}{*}{$\begin{array}{c}c 2=6.67 \\
p<0.154\end{array}$} & 21.5 & \multirow{3}{*}{$\begin{array}{c}\mathrm{c} 2=14.24 \\
\mathrm{p}<0.007\end{array}$} \\
\hline Medium & 13.0 & & 51.4 & & 39.8 & & 6.5 & \\
\hline High & 38.2 & & 53.0 & & 28.4 & & 19.7 & \\
\hline \multicolumn{9}{|l|}{$\begin{array}{l}\text { Standard of } \\
\text { living index }\end{array}$} \\
\hline Low & 28.0 & $c 2=5.47$ & 50.4 & $c 2=3.47$ & 28.9 & $c 2=5.16$ & 14.9 & $\mathrm{c} 2=9.34$ \\
\hline Medium & 20.2 & $\mathrm{p}<0.242$ & 53.9 & $\mathrm{p}<0.483$ & 41.5 & $\mathrm{p}<0.271$ & 11.2 & $\mathrm{p}<0.053$ \\
\hline High & 28.4 & & 59.0 & & 37.5 & & 14.7 & \\
\hline Total & 25.7 & & 54.2 & & 35.5 & & 13.7 & \\
\hline
\end{tabular}

workers. Further, Hindu workers were more aware of respiratory problems (33\%), skin complaints (55\%), and gastrointestinal problems (16\%) as compared to Muslim workers. Similarly, other caste group workers were also more aware of respiratory problems (29\%), eye-related issues (46\%), and the gastrointestinal problem (19\%) compared to the schedule caste and other caste group workers.

Qualitative measure of environmental exposure by type of work 
The chemicals used in tanning processes are not consumed but discharged into the environment as effluents. Effluents contain organic matter, chromium, sulphides, and solid waste. Qualitative assessment of exposure at the workplace may be a useful tool for evaluating hazardous working conditions. Table 5 presents qualitative measures of environmental exposure by different work categories. The results show that more than half (54\%) of the workers engaged in beam housework followed by wet finishing (44\%) and miscellaneous work (43\%) had moderate to high exposure to chemicals. About one-third of Beamhouse workers (33\%) and over a quarter (26\%) of the wet finishing had moderate to high dermal contact with the chemicals. Further, 63 percent of the workers engaged in Beamhouse work, 51 percent doing miscellaneous work, 47 percent in wet finishing, and $36 \%$ in dry finishing reported exposure to dust. Furthermore, 50 percent of the beam house workers, 43 percent workers in wet finishing, 34 percent in miscellaneous work, and 30 percent in dry finishing had moderate to high exposure to ergonomic stressors.

Tale 5: Qualitative measures of environmental exposure by their type of work among the tannery workers

\begin{tabular}{|c|c|c|c|c|c|c|}
\hline & $\begin{array}{l}\text { Beam } \\
\text { house }\end{array}$ & $\begin{array}{c}\text { Wet } \\
\text { finishing }\end{array}$ & $\begin{array}{c}\text { Dry } \\
\text { finishing }\end{array}$ & $\begin{array}{c}\text { Miscellaneous } \\
\text { work }\end{array}$ & Chi-square & $\mathbf{N}$ \\
\hline \multicolumn{7}{|c|}{ Chemicals in the Air ${ }^{1}$} \\
\hline No exposure & 25.0 & 24.3 & 30.1 & 17.0 & \multirow{3}{*}{$\begin{array}{l}\mathrm{c} 2=8.09 \\
\mathrm{p}<0.231\end{array}$} & 74 \\
\hline Low exposure & 20.8 & 31.4 & 37.1 & 40.4 & & 99 \\
\hline $\begin{array}{l}\text { Moderate/ High } \\
\text { exposure }\end{array}$ & 54.2 & 44.3 & 32.8 & 42.6 & & 111 \\
\hline \multicolumn{7}{|c|}{ Dermal exposure to chemicals ${ }^{2}$} \\
\hline No exposure & 33.3 & 24.3 & 32.2 & 17.0 & \multirow{3}{*}{$\begin{array}{c}\mathrm{c} 2=16.43 \\
\mathrm{p}<0.012\end{array}$} & 79 \\
\hline Low exposure & 33.3 & 50.0 & 49.0 & 74.5 & & 148 \\
\hline $\begin{array}{l}\text { Moderate/ High } \\
\text { exposure }\end{array}$ & 33.4 & 25.7 & 18.8 & 8.5 & & 57 \\
\hline \multicolumn{7}{|l|}{ Airborne dust ${ }^{3}$} \\
\hline No exposure & 25.0 & 21.4 & 34.3 & 17.0 & \multirow{3}{*}{$\begin{array}{c}c 2=12.28 \\
p<0.056\end{array}$} & 78 \\
\hline Low exposure & 12.5 & 31.4 & 29.3 & 31.9 & & 82 \\
\hline $\begin{array}{l}\text { Moderate/ High } \\
\text { exposure }\end{array}$ & 62.5 & 47.2 & 36.4 & 51.1 & & 124 \\
\hline \multicolumn{7}{|c|}{ Ergonomic stressors 4} \\
\hline No exposure & 20.8 & 18.6 & 37.1 & 19.2 & \multirow{3}{*}{$\begin{array}{c}c 2=14.15 \\
\mathrm{p}<0.028\end{array}$} & 80 \\
\hline Low exposure & 29.2 & 38.6 & 32.8 & 46.8 & & 103 \\
\hline $\begin{array}{l}\text { Moderate/ High } \\
\text { exposure }\end{array}$ & 50.0 & 42.8 & 30.1 & 34.0 & & 101 \\
\hline Total & 100.0 & 100.0 & 100.0 & 100.0 & & 284 \\
\hline
\end{tabular}

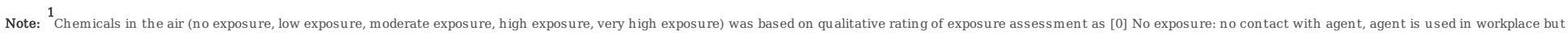

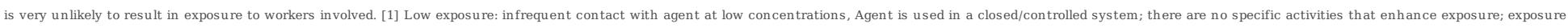

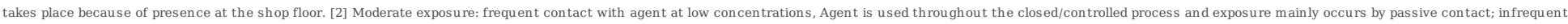

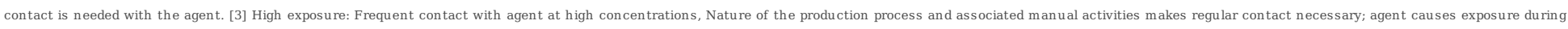

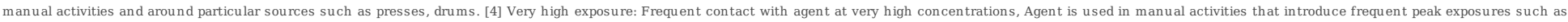

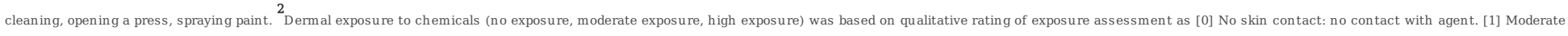

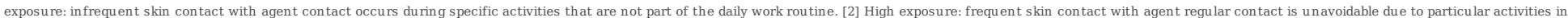

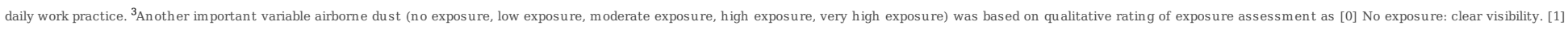

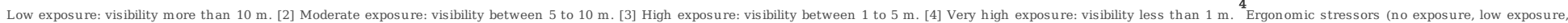




\section{Preventive measure and experiencing the different working condition}

The preventive and safety measures appropriate for the work are presented in Table 6. The highest use of gloves and masks is seen in Beamhouse work (12 \& 13\% respectively), wet finishing (10 \& 16\%), miscellaneous (9 \& 17\%), and dry finishing (6.3 \& 9\%). Most tannery workers (69-92\%), temporary as well as permanent, reported that they were involved in loading and unloading of raw hides manually in tannery premises. Only a small proportion (4.3-10\%) used trolleys for loading and unloading. A substantial proportion of tannery workers had high exposure to humidity (69-88\%), heat (69-84\%), noise (78-87\%). Additionally, most (51-63\%) had become accustomed to the smell of hide. Most tannery workers also reported that exhaust fans (88-99\%).

Table 6: Percentage of tannery workers who use preventive measures and experienced different environmental conditions in tannery premises by their type of work

\begin{tabular}{|c|c|c|c|c|c|c|}
\hline Variables & Beam house & Wet finishing & Dry finishing & Miscellaneous work & Overall & Number $(\mathrm{N})$ \\
\hline \multicolumn{7}{|c|}{ Use of glove } \\
\hline Often & 12.5 & 10.0 & 6.3 & 8.5 & 8.1 & 23 \\
\hline Sometimes & 41.7 & 50.0 & 51.7 & 42.6 & 48.9 & 139 \\
\hline Never & 45.8 & 40.0 & 42.0 & 48.9 & 43.0 & 122 \\
\hline \multicolumn{7}{|l|}{ Use of mask } \\
\hline Often & 12.5 & 15.7 & 9.0 & 17.0 & 12.3 & 35 \\
\hline Sometimes & 29.2 & 48.6 & 49.0 & 42.6 & 46.1 & 131 \\
\hline Never & 58.3 & 35.7 & 42.0 & 40.4 & 41.6 & 118 \\
\hline \multicolumn{7}{|c|}{ Involved in loading and unloading of raw hides manually } \\
\hline Yes & 91.7 & 90.0 & 69.2 & 87.2 & 79.2 & 225 \\
\hline No & 8.3 & 10.0 & 30.8 & 12.8 & 20.8 & 59 \\
\hline \multicolumn{7}{|c|}{ Involved in loading and unloading of raw hides by trolley } \\
\hline Yes & 8.3 & 8.6 & 9.8 & 4.3 & 8.5 & 24 \\
\hline No & 91.7 & 91.4 & 90.2 & 95.7 & 91.5 & 260 \\
\hline \multicolumn{7}{|c|}{ Feeling humidity in tannery premises } \\
\hline Yes & 87.5 & 84.3 & 68.5 & 72.3 & 74.7 & 212 \\
\hline No & 12.5 & 15.7 & 31.5 & 27.7 & 25.3 & 72 \\
\hline \multicolumn{7}{|c|}{ Feeling heat in tannery premises } \\
\hline Yes & 79.2 & 84.3 & 69.2 & 80.8 & 75.7 & 215 \\
\hline No & 20.8 & 15.7 & 30.8 & 19.2 & 24.3 & 69 \\
\hline \multicolumn{7}{|c|}{ Feeling extreme noise in tannery premises } \\
\hline Yes & 83.3 & 87.1 & 78.3 & 85.1 & 82.0 & 233 \\
\hline No & 16.7 & 12.9 & 21.7 & 14.9 & 18.0 & 51 \\
\hline \multicolumn{7}{|c|}{ Comfortable with smell of hides } \\
\hline Yes & 62.5 & 51.4 & 54.6 & 53.2 & 54.2 & 154 \\
\hline No & 37.5 & 48.6 & 45.5 & 46.8 & 45.8 & 130 \\
\hline \multicolumn{7}{|c|}{ Exhaustive fan } \\
\hline Yes & 87.5 & 98.6 & 96.5 & 95.7 & 96.3 & 273 \\
\hline No & 12.5 & 1.4 & 3.5 & 4.3 & 3.7 & 11 \\
\hline Total & 100.0 & 100.0 & 100.0 & 100.0 & 100.0 & 284 \\
\hline
\end{tabular}

\section{Discussion}


The results from this study of male tannery workers in Kanpur, Uttar Pradesh demonstrated that the workers were exposed to chemicals, leather dust, which contains chromium, and physical hazards. A substantial proportion of the tannery workers reported awareness of the health risks of the various tanning processes. The physical and cognitive difficulty levels of the job in tanneries were similar to previous studies $[8,9,10]$. It is essential to mention here that there are very few studies conducted on tannery workers in the Indian context.

The results of our study validate the need for further efforts to minimize hazardous occupational health risks among tannery workers. However, findings depict tannery workers aged 36 years \& above are less likely to be aware of the hazardous work environment, and malignant tissues involved in the tanning process, lack of protective equipment and safety devices showed a significant double risk for occupational health and injuries $[11,12,13,14]$. Previous findings agree with a study on salt workers found that there is a considerable gap between their knowledge and practices, along with protective measures [15]. A study conducted on chronic conditions, workplace safety, and job demands in Colorado revealed that non-provision of workplace safety led to employees' chronic health conditions and contributed to absenteeism and poor job performance. It also influences the physical and cognitive difficulties of the workers associated with the work [16]. Other factors also significantly affect perceptions of health risks: age, education, religion, caste, media exposure, and standard of living index. Workers reported that they are aware that they have the chance of getting respiratory problems, skin complaints, eye-related, and gastrointestinal problems from the tannery. A substantial proportion of workers experienced severe conditions, such as humidity (69-88\% of those surveyed), heat (69-84\%), noise (78-87\%); they had also got used to the smell of hides (51-63\%). Comparable outcomes found by a study led in some developing countries concentrating on the upshot of work-related acquaintance to noise and heat on the health of the workers. Results portray that those who worked in the foundry had high thermal stress, high noise levels, high visual defects, high muscle cramps problem, high visual disability and also describe non-use of protective equipment and poor occupational hygiene and safety measures were also affected the health problem among workers $[17,18,19,20]$. Our study recommended that leather dust exposure be reduced by providing gloves and masks and by installing a hood duct to provide better ventilation and removal of leather dust from the work area as also recommended by previous researches [21].

This research also suggested risks should be assessed for their potential consequences on health. Liquid effluents contain organic matter, chromium, sulfides, and solid wastes. A qualitative assessment of exposure showed that moderate to high exposure to chemicals and also contacted them. It has been reported from the literature that the workers on exposure to leather dust, which contains chromium in the protein-bound form, exhibited a higher mean concentration of urinary and blood chromium [8]. The workers engaged in beam housework, miscellaneous work, wet finishing, and dry finishing also reported moderate to high exposure to dust and ergonomic stressors. The use of safety gear was the highest in beam housework, followed by wet finishing, miscellaneous work, and dry finishing. This study also recognized a lack of awareness of the health risks in tannery operations and shortcomings in the use of preventive measures. Employers must raise awareness of health risks and ensure compliance with safety measures. But at the same time, qualitative results of focused group discussion with workers from small scale industries in Tanzania show high levels (> $90 \%$ ) of self-reported exposure to health problems, and low use of protective measures [22]. In continuation of the previous findings, a case study of electroplating sector workers in the United Kingdom showed that the employees had sound knowledge of the hazardous nature of chemicals used at the workplace [23].

An intervention study focused on prevention of work-related skin problems assessed the occupational health and safety among wet workers. The study found significant behavior change and fewer skin problems among workers in the intervention ( $n=207$ ) group as compared to the control group $(n=168)$. The intervention was successful in enhancing knowledge and changing behavior [24]. Literature suggests the majority of workers had an essential awareness of the existence of occupational health and safety legislation, but they were unaware of their legal responsibilities. They were found to have minimal occupational and safety training $[25,26,27,28,29]$. 


\section{Conclusion}

The outcomes of the study give a clear indication of the effect of the workstation environment on the health status of workers and require the use of adequate measures to improve the facilities and thereby the health status of tannery workers.

\section{Abbreviations}

ILO

International Labour Organization

WHO

World Health Organizations

DALY

Disability Adjusted Life Years

PPS

Probability Proportional to Size

OR

Odds Ratio

$\mathrm{Cl}$

Confidence Interval

\section{Declarations}

\section{Ethics approval and consent to participate:}

We have received ethical approval from the board. The Student Research Ethics Committee approved the study of the International Institute for Population Sciences Mumbai, India. We have also obtained consent to participate from each of the respondents before starting the interview. The confidentiality of information has been maintained.

\section{Consent for publication}

Not applicable

Availability of supporting data: This research is based on primary data.

\section{Competing interests}

The authors declare that they have no conflict of interest.

\section{Funding}

Not received any funding

\section{Authors' contributions:}

GCK developed the questionnaire, collected the data, contributed in acquisition of data. SKS PC conceived and designed the experiments. GCK PC analysed the data. GCK PC wrote the manuscript. SKS critically revised the draft.

Acknowledgements: Not applicable

Authors' information: 
Gyan Chandra Kashyap: Assistant Professor at Institute of Health Management Research, 319, Near Thimmareddy Layout, Hulimangala Post Electronic City Phase-1, Bangalore-560105, India Email: gyan@iihmr.org Contact number: +919967162925. Praveen Chokhandre: Research Analyst, GEH, International Institute for Population Sciences, Govandi Station Road Donor Mumbai, 400088, India Email: praveenchokhandre@gmail.com. Shri Kant Singh: Professor, Department of Mathematical Demography \& Statistics International Institute for Population Sciences, Govandi Station Road Deonar Mumbai, 400088, India, Email: sksingh31962@gmail.com.

\section{References}

[1] International Labour Organization (ILO). Occupational safety and health (OSH). 2019;

https://www.ilo.org/moscow/areas-of-work/occupational-safety-andealth/WCMS_249278/lang-en/index.htm.

[2] Neira M. Towards a healthier future of work. (WHO, 2019)

https://www.ilo.org/safework/events/safeday/33thinkpieces/WCMS_681618/lang- $\quad$ en/index.htm

[3] Neira M, Pfeiffer M, Campbell-Lendrum D, Prüss-Ustün A. Towards a healthier and safer environment. The Lancet. 2018 Feb 3; 391(10119):408-10.

[4] Prüss-Ustün A, van Deventer E, Mudu P, Campbell-Lendrum D, Vickers C, Ivanov I, Forastiere F, Gumy S, Dora C, Adair-Rohani H, Neira M. Environmental risks and non-communicable diseases. Bmj. 2019 Jan 28; 364:I265.

[5] World Health Organization. Healthy environments: why do the matter and what can we do?. World Health Organization; 2019.

[6] World Health Organization. Occupation Health. 2019; https://www.who.int/topics/occupational_health/en/

[7] World Health Organization. The world health report 2002: reducing risks, promoting healthy life. World Health Organization; 2002.

[8] Rastogi SK, Pandey A, Tripathi S. Occupational health risks among the workers employed in leather tanneries at Kanpur. Indian journal of occupational and environmental medicine. 2008 Dec; 12(3):132.

[9] Ravi R. Impact of workplace environment on health of leather factory workers. International Journal of Community Medicine and Public Health. 2017 Jul 22; 4 (8):2674- $\quad 80$.

[10] Islam R, Hossain MS, Siddique MA. Occupational health hazards and safety practices among the workers of tannery industry in Bangladesh. Jahangirnagar University Journal of Biological Sciences. 2017 Aug 27; 6(1):13-22.

[11] Bull N, Riise T, Moen BE. Work-related injuries and occupational health and safety factors in smaller enterprises-a prospective study. Occupational Medicine. 2002 Mar 1; 52(2):70- 4.

[12] Hämäläinen P, Saarela KL, Takala J. Global trend according to estimated number of occupational accidents and fatal work-related diseases at region and country level. Journal $\quad$ of safety research. 2009 Jan 1; 40(2):125-39.

[13] Takala J, Hämäläinen P, Saarela KL, Yun LY, Manickam K, Jin TW, Heng P, Tjong C, Kheng LG, Lim S, Lin GS. Global estimates of the burden of injury and illness at work in 2012. Journal of occupational and environmental hygiene. 2014 May 4; 11(5):326-37. 
[14] Turkkan A, Pala K. Trends in occupational injuries and fatality in Turkey. International occupational safety and ergonomics. 2016 Oct 1; 22(4):457-62. journal of

[15] Haldiya KR, Sachdev R, Mathur ML, Saiyed HN. Knowledge, attitude and practices related to
occupational health problems among salt workers working in the desert of occupational health. 2005; 47(1):85-8.

[16] Jinnett K, Schwatka N, Tenney L, Brockbank CV, Newman LS. Chronic conditions, workplace safety, and job demands contribute to absenteeism and job performance. Health $\quad$ Affairs. 2017 Feb 1; 36 (2):237-44.

[17] Gomes J, Lloyd OL, Revitt DM. The influence of personal protection, environmental hygiene and exposure to pesticides on the health of immigrant farm workers in a desert country. International archives of occupational and environmental health. 1999 Jan 1; 72(1):40-5.

[18] Gomes J, Lloyd O, Norman N. The health of the workers in a rapidly developing country: effects of occupational exposure to noise and heat. Occupational medicine. 2002 May $\quad$ 1; 52(3):121-8.

[19] Hubbard R. Occupational dust exposure and the aetiology of cryptogenic fibrosing alveolitis. European Respiratory Journal. 2001 Jul 1; 18(32 suppl):119s-21s.

[20] Chandrasekaran V, Dilara K, Padmavathi R. Pulmonary functions in tannery workers-a cross sectional study. Indian journal of physiology and pharmacology. 2014 Jul; 58(3):206- 10.

[21] Thepaksorn P, Thongjerm S, Incharoen S, Siriwong W, Harada K, Koizumi A. Job safety analysis and hazard identification for work accident prevention in para rubber wood sawmills in southern Thailand. Journal of occupational health. 2017:16-0204.

[22] Rongo LM, Barten FJ, Msamanga GI, Heederik D, Dolmans WM. Occupational exposure and health problems in small-scale industry workers in Dar es Salaam, Tanzania: a situation analysis. Occupational Medicine. 2004 Jan 1; 54(1):42-6.

[23] Sadhra S, Petts J, McAlpine S, Pattison H, MacRae S. Workers' understanding of chemical risks: electroplating case study. Occup Environ Med. 2002 Oct 1; 59(10):689-95.

[24] Held E, Mygind K, Wolff C, Gyntelberg F, Agner T. Prevention of work related skin problems: an intervention study in wet work employees. Occupational and Environmental Medicine. 2002 Aug 1; 59 (8):556-61.

[25] Fonteyn PN, Olsberg D, Cross JA. Small business owners' knowledge of their occupational health and safety (OHS) legislative responsibilities. International Journal of Occupational Safety and Ergonomics. 1997 Jan 1; 3(12):41-57.

[26] Salvador LR, Van Thinh D. Occupational Safety and Health: An overview. In 2016 IEEE 11th International Symposium on Applied Computational Intelligence and Informatics (SACI) 2016 May 12 (pp. 355-360). IEEE.

[27] Walters DR. Preventive Services in Occupational Health and Safety in Europe: Developments and trends in the 1990s. International journal of health services. 1997 Apr; $\quad$ 27(2):247-71.

[28] Collinson DL. Surviving the rigs': Safety and surveillance on North Sea oil installations. Organization studies. 1999 Jul; 20(4):579-600. 
[29] Isaksson K, Hellgren J, Pettersson P. Repeated downsizing: Attitudes and well-being for surviving personnel in a

\section{Figures}

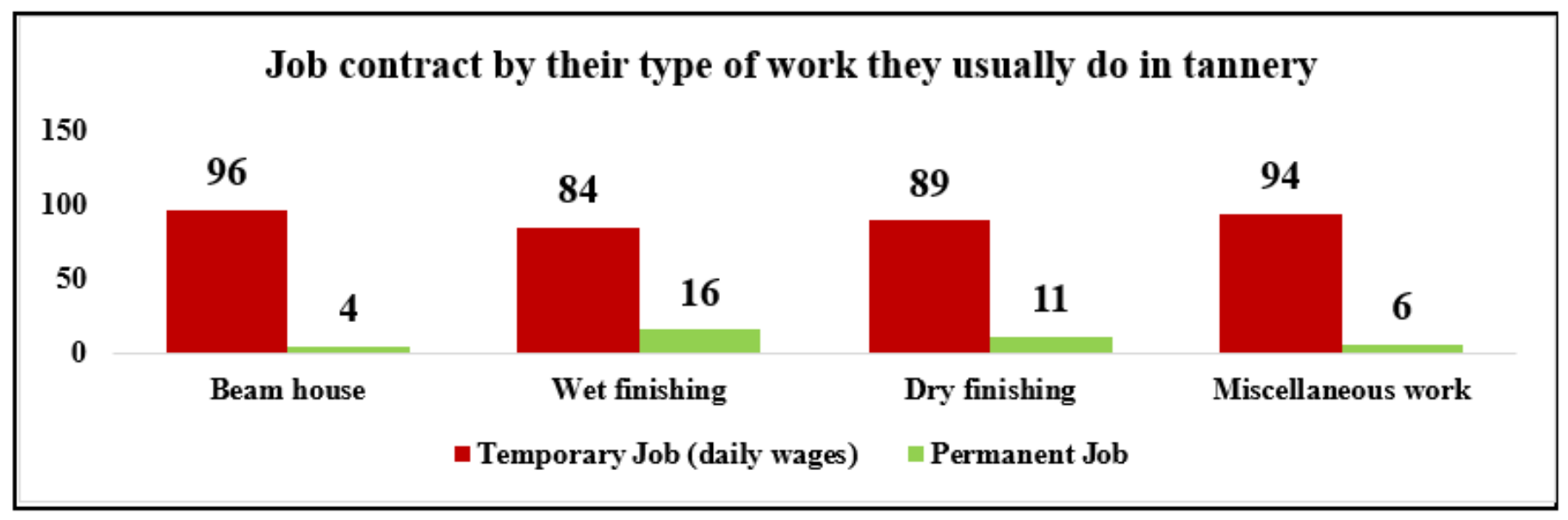

Figure 1

Percent distribution of job contract by their type of work they usually do in tannery reported by tannery workers 